\title{
Are nurses updated on the proper management of patients with
} sepsis?

\author{
Os enfermeiros estão atualizados para o manejo adequado do paciente com sepse? \\ ¿Los enfermeros están actualizados para el manejo adecuado del paciente con sepsis?
}

\author{
Layala de Souza Goulart ${ }^{1}$ (1) \\ Marcos Antonio Ferreira Júnior ${ }^{1}$ (D) \\ Elaine Cristina Fernandes Baez Sarti ${ }^{1}$ \\ Álvaro Francisco Lopes de Sousa² (1) \\ Adriano Menis Ferreira ${ }^{1}$ (C) \\ Oleci Pereira Frota ${ }^{1}$ (C)
}

1. Universidade Federal de Mato Grosso do Sul. Campo Grande, MS, Brasil.

2. Universidade Nova de Lisboa.

Lisboa, Portugal.
Corresponding author:

Oleci Pereira Frota.

E-mail: olecifrota@gmail.com

Submitted on 01/21/2019.

Accepted on 06/23/2019.

DOI: 10.1590/2177-9465-EAN-2019-0013

\section{Abstract}

Objective: To evaluate nurses' knowledge about the definitions of Sepsis-3 and updates to the Surviving Sepsis Campaign. Methods: This descriptive study was carried out from July to August 2018, with 30 nurses from four wards of a large university hospital. For data collection, we created, structured, and validated a questionnaire composed of socio-demographic/occupational data and knowledge test. Results: Only $16.6 \%$ of the professionals received in-service training on the subject. There was no implementation of sepsis protocols in the institution, although $96.6 \%$ of the participants considered their implementation necessary. Professionals aged $\geq 35$ years old had a higher level of knowledge about the new definition of sepsis $(p=0.042)$. The knowledge about volume resuscitation $(p=0.001)$ and use of vasopressors $(p=0.025)$ was greater in those with $\geq 10.5$ years of experience in the profession. Nurses from the clinical units presented a higher level of knowledge about the organic dysfunctions caused by sepsis $(p=0.025)$. Conclusion and implications for the practice: Nurses do not have satisfactory knowledge for the proper identification, treatment, and clinical management of sepsis. There is a need for greater professional, institutional, and politica incentives to implement a permanent education and the sepsis protocol.

Keywords: Nursing; Critical Care; Hospital Infection; Employee Performance Appraisal.

\section{REsUMO}

Objetivo: Avaliar o conhecimento dos enfermeiros que atuam em enfermarias sobre as definições do Sepsis-3 e atualizações da Surviving Sepsis Campaign. Métodos: Estudo descritivo realizado de julho a agosto de 2018 com 30 enfermeiros de quatro enfermarias de um hospital universitário de grande porte. Para coleta de dados, criamos, estruturamos e validamos um questionário composto por dados sociodemográficos/ocupacionais e teste de conhecimento. Resultados: Apenas 16,6\% dos profissionais receberam treinamento em serviço sobre o tema. Na instituição não havia protocolo de sepse implantado, embora 96,6\% dos participantes tenham considerado sua implantação necessária. Profissionais com idade $\geq 35$ anos apresentaram maior nível de conhecimento acerca da nova definição de sepse $(p=0,042)$. O conhecimento sobre ressuscitação volêmica $(p=0,001)$ e uso de vasopressores $(p=0,025)$ foi maior naqueles com tempo $\geq 10,5$ anos de exercício na profissão. Enfermeiros das unidades clínicas apresentaram maior nível de conhecimento das disfunções orgânicas causada pela sepse $(p=0,025)$ Conclusão e implicações para a prática: Os enfermeiros não apresentam conhecimento satisfatório para identificação tratamento e gerenciamento clínico da sepse de forma adequada. Existe a necessidade de maiores incentivos profissionais, institucionais e políticos, com vistas às implementações da educação permanente e do protocolo de sepse.

Palavras-chave: Enfermagem; Cuidados Críticos; Infecção Hospitalar; Avaliação de Desempenho Profissional.

\section{Resumen}

Objetivo: Evaluar el conocimiento de los enfermeros que actúan en enfermerías sobre las definiciones de Sepsis-3 y las actualizaciones de Surviving Sepsis Campaign. Métodos: Estudio descriptivo realizado de julio a agosto de 2018 con 30 enfermeros de cuatro enfermerías de un hospital universitario de gran porte. Para la recolección de datos, creamos, estructuramos y validamos una encuesta compuesta de datos sociodemográficos/ocupacionales y tests de conocimiento. Resultados: Solo e $16,6 \%$ de los profesionales recibieron capacitación en servicio sobre la temática. En la institución no había protocolo de sepsis implantado, aunque el $96,6 \%$ de los participantes consideraron su implantación necesaria. Los profesionales con edad $\geq 35$ años presentaron mayor nivel de conocimiento acerca de la nueva definición de sepsis $(p=0,042)$. El conocimiento sobre la resucitación volémica $(p=0,001)$ y el uso de vasopresores $(p=0,025)$ fue mayor en aquellos con tiempo $\geq 10,5$ años de ejercicio en la profesión. Los enfermeros de las unidades clínicas presentaron un mayor nivel de conocimiento de las disfunciones orgánicas causadas por la sepsis $(p=0,025)$. Conclusión e implicaciones para la práctica: Los enfermeros no presentan un conocimiento satisfactorio para identificar, tratar y administrar clinicamente la sepsis de forma adecuada. Existe la necesidad de mayores incentivos profesionales, institucionales y políticos, con miras a implementar una educación permanente y un protocolo de sepsis.

Palabras clave: Enfermeria; Cuidados Críticos; Infección Hospitalaria; Evaluación del Desempeño de los Empleados. 


\section{INTRODUCTION}

Redefined in 2016 as a life-threatening organic dysfunction secondary to the body's unregulated response to infection, ${ }^{1}$ sepsis affects approximately 30 million people worldwide each year. Overall mortality is about $25-30 \%$, and almost twice as much (40-50\%) in underdeveloped countries and in patients with complications. ${ }^{2}$ In Brazil, numbers have increased considerably. From 2006 to 2015 , the annual incidence of sepsis increased by $50.5 \%$, from $31.5 / 100,000$ to $47.4 / 100,000$ people per year. Mortality increased by $85 \%$ (13.3/100,000 to $24.6 / 100,000$ people per year) and lethality by $23 \%(42.7 \%$ to $51.1 \%)$ in the same period. ${ }^{3}$ This places sepsis as a major public health problem nowadays and highlights the need to implement effective coping strategies.

In the hospital context, data from the literature indicates that $93 \%$ of patients develop sepsis outside the $\mathrm{ICU}^{4}$ and $43.3 \%$ are hospitalized with organic dysfunction associated to sepsis. ${ }^{5}$ This highlights the need for the multi-professional team of the emergency room and the hospitalization units to be able to identify presumptive signs and symptoms of sepsis early, especially nurses, who are usually closer to the patients. This need facilitates treatment, decreases morbidity and mortality rates, reduces hospitalization time, patient and family suffering, and health system costs. ${ }^{4-6}$

However, studies carried out in Brazil $^{7,8}$ and abroad ${ }^{9,10}$ show poor knowledge of nurses on the subject. It is known that the level of knowledge shorter than expected can start from the training, as revealed in a study that evaluated the knowledge of the graduates of nursing undergraduate courses on sepsis. ${ }^{11}$ In this study, more than half of the students reported receiving "little" information in the course about the signs and symptoms of sepsis and many academics were unaware of the definition of sepsis. In the practice of care, an audit ${ }^{10}$ conducted in the United Kingdom with nurses from inpatient units revealed insufficient knowledge about signs and symptoms of sepsis and some aspects of their initial management, showing a critical situation, therefore worthy of investments.

Although there are studies on the knowledge of nurses about sepsis, ${ }^{7-10}$ it is emphasized that they were based on definitions, diagnostic methods, and treatment and management bundles no longer in line with the new definitions and guidelines. Two years after redefining sepsis 1 and replacing the 3 and 6 hour bundles by the 1 hour bundle of the Surviving Sepsis Campaign (SSC),,$^{12}$ there are still no studies that evaluated whether nurses' knowledge is consistent with these updates. Thus, the objective of this study was to evaluate nurses' knowledge about the definitions of the Sepsis-3 and updates of SCC.

\section{METHOD}

This is a descriptive and cross-sectional study developed in four sectors of hospital wards - Infectious and Parasitic Diseases (IPD), Surgical Clinics I (SC-I), Surgical Clinic II (SC-II), and Medical Clinic (MC) - which provide care to adult patients of a large university hospital in Mato Grosso do Sul. IPD is the only state hospitalization unit dedicated to treating patients affected by IPD. MC provides care for patients with clinical conditions of the most varied medical specialties, whose beds are mostly occupied by the elderly and bedridden patients. SC-I receives patients from several types of surgeries (general); while SC-II predominantly receives patients from orthopedic and urological surgeries.

The study population consisted of 35 nurses, including caregivers and technical staff. All nurses working in the investigated sectors who voluntarily accepted to participate in the study, and with at least six months of professional experience in these units, were included. Three nurses were excluded for less than six months of experience in the wards, one for medical leave, and one for maternity leave. Thus, 30 nurses participated

Data was collected between July and August 2018. For this, a structured questionnaire was used, consisting of items related to socio-demographic/occupational data and a theoretical knowledge test on identification, treatment, and management of sepsis. The test was created based on the Third International Consensus Definitions for Sepsis and Septic Shock, 1 in the sepsis management protocol of the Latin American Sepsis Institute,${ }^{13}$ and in the update of SSC, ${ }^{14}$ used as parameters for setting hits or errors.

In order to verify the objectivity, relevance, and clarity of the items, according to the methodological process of previous study, ${ }^{15}$ the instrument was reviewed by five judges with technical and scientific knowledge about the subject: one with experience in validation of scales, two researchers who research the thematic, and two specialists in intensive care. There were discrete adjustments in the writing of the questions, based on the opinions and discussion between the authors. The pilot test revealed no need for instrument changes.

The knowledge test consisted of 10 questions (Chart 1). An analysis was made to show which correct alternatives were most correctly answered and which incorrect ones were mostly mistakenly marked as the correct ones. For compilation purposes, questions marked as "Does not know" were considered wrong. For data collection, nurses were grouped on site - in a specific room, during normal working hours - and oriented on the objectives of the research, their relevance, and method of data collection. After reading, signing, and delivering 
Chart 1. Theoretical knowledge test on identification, treatment, and management of sepsis. Campo Grande, MS, Brazil, 2018.

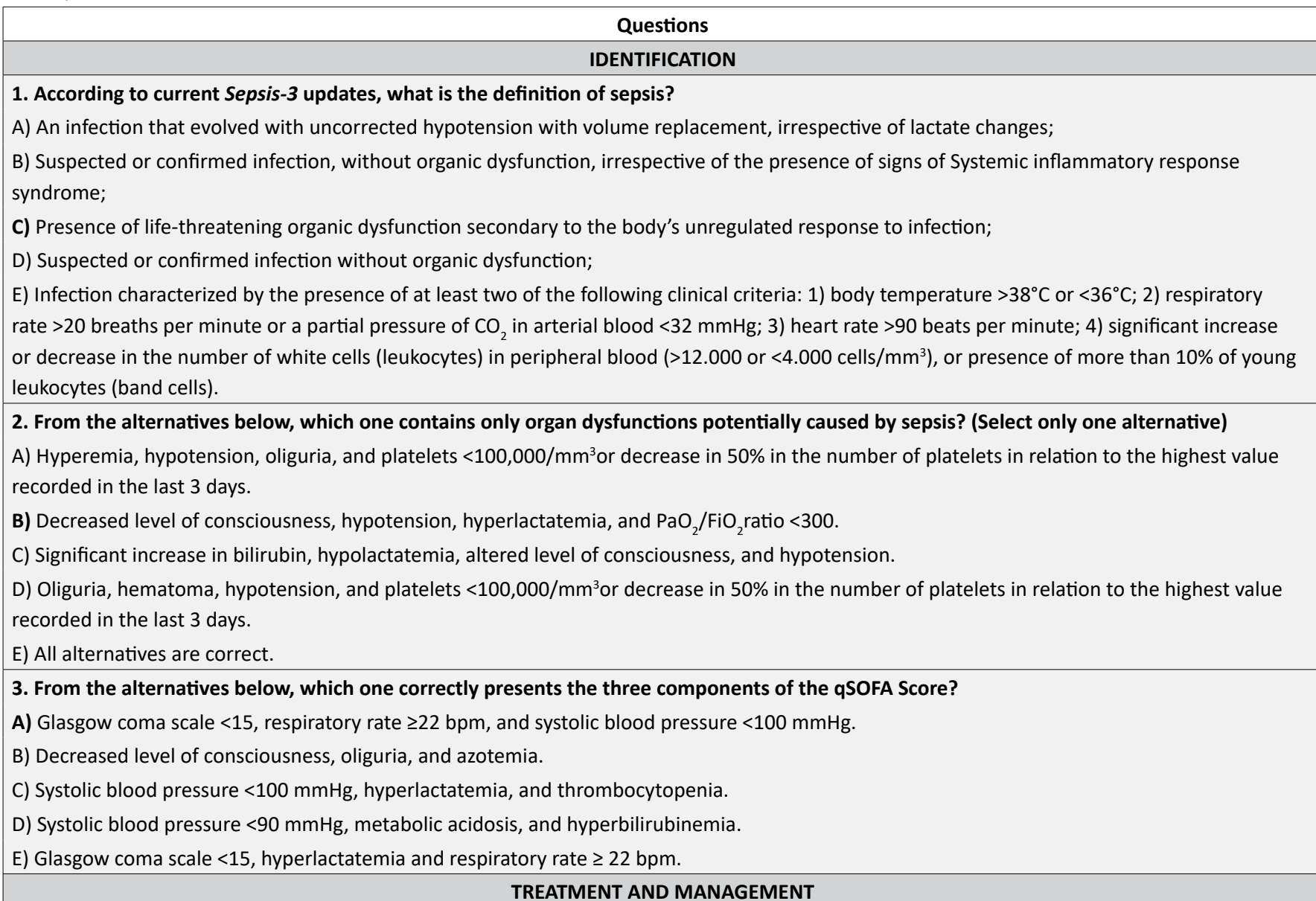

4. A $70 \mathrm{~kg}$ patient - diagnosed with sepsis, hypotension, and signs of hypoperfusion - received volume resuscitation of $1,400 \mathrm{ml}$ of $0.9 \%$ saline. Is the volume infused in accordance with the guidelines for immediate volume replacement?

( ) Yes (X) No ( ) Does not know

5. The use of vasopressors is indicated for patients who remain with average blood pressure $\leq 75 \mathrm{mmHg}$ (during or after infusion of volume), noradrenaline being the drug of first choice.

( ) Yes (X) No ( ) Does not know

6. Is the recommended time for initiation of intravenous antimicrobial therapy up to one hour after the recognition of sepsis and septic shock? (X) Yes ( ) No ( ) Does not know

7. Protein colloids, albumin, and albumin serum are contraindicated as initial resuscitation fluids.

( ) Yes (X) No ( ) Does not know

8. Should blood from two different sites be collected in all viable patients with suspected sepsis?

(X) Yes ( ) No ( ) Does not know

9. Is the use of bicarbonate contraindicated in cases of lactic acidosis in patients with $\mathrm{pH}>7.15$ ?

(X) Yes ( ) No ( ) Does not know

10. Select the alternative that contains the perfusion parameters that can be reevaluated after volume resuscitation.

A) Level of consciousness, diuresis, temperature, and vena cava distensibility.

B) Measurement of central venous saturation, respiratory rate, capillary filling time, and diuresis.

C) Pulse pressure variation, vena cava distensibility, lactate level, and level of consciousness.

D) Capillary filling time, elevated creatinine, elevated blood pressure, and $\mathrm{O}_{2}$ saturation.

E) All alternatives are correct

Source: Created by the authors. Note: Alternatives written in bold type or marked with " $\mathrm{X}$ " correspond to the template. 
the Informed Consent Form, each professional received the questionnaire. It was answered without consulting any source of information, with direct observation of the researcher. There was no time limitation for completing the questionnaire.

The obtained data was compiled, analyzed, and compared with the existing knowledge on the subject. As used by a similar study, ${ }^{16}$ the level of knowledge of the participants was classified according to the following scoring diagram: $\leq 59 \%$ "poor knowledge", from 60 to 69 "bad", from 70 to 79 "regular", from 80 to 89 "good", from 90 to 99 "very good" and $100 \%$ rated "excellent knowledge". Data was analyzed using descriptive and inferential statistics. The nurses' socio-demographic and occupational data were compared to the percentage of correctness in the questions by means of Chi-Square test or Fischer's exact test. A significance level of $5 \%$, equivalent to $p<0.05$, was adopted.

This study was approved by the Research Ethics Committee with Human Beings of the Federal University of Mato Grosso do Sul, under opinion No. 2,685,746 and followed the national and international research ethics standards.

\section{RESULTS}

The study was carried out with 30 nurses, of these $24(80 \%)$ caregivers and six $(20 \%)$ assistants and heads of unit. The female sex predominated $(76.7 \%)$ and the average age was 35 years old \pm 5.5 . Of the participants, $6.7 \%$ presented education and experience as a Nursing Assistant. With respect to the higher degree, specialization predominated $(70 \%)$, followed by the Master's degree (16.7\%), graduation (10\%), and Doctor's degree (3.3\%). The professionals had an average time in profession of 10.5 years $( \pm 4.2)$ and average time in profession in the hospitalization unit of 3.7 years $( \pm 3.8)$. The predominant work shift was the day shift $(60 \%)$ followed by the night shift $(40 \%)$. Nine $(30 \%)$ participants were working in SC-I, nine $(30 \%)$ in MC, six $(20 \%)$ in SC-II, and six (20\%) in IPD.

Regarding the performance in the questionnaire, question 8 (based on the indication of the blood culture collection) was the one that presented the highest percentage of correctness $(90 \%)$ with a level of knowledge classified as "very good". The others exhibited $<60 \%$ correctness, thus classified as "poor knowledge". Four statistically significant associations were found between the number of correctly answered questions and the socio-demographic/occupational data of the nurses (Figure 1).

The incorrect alternatives most frequently pointed out as correct by the participants were: question 1 alternative "E" (63.4\%); question 2, "E" (30\%); question 3, "E" (20\%); question 4, "Does not know" (56.7\%); question 5, "Yes" (60\%); question 6 "No" (33.3\%); question 7, "Yes" (56.7\%); question 8, "No" (10\%); question 9, "No" (46.7\%); and question 10, alternative "E" (43.3\%).
Figure 1. Percentage of correctness, level of knowledge and statistical association of the questions answered by the nurses. Campo Grande/MS, Brazil, $2018(n=30)$. Note: Highest level of correctness in the question associated with: * age $\geq 35$ years old ( $p=0.042$ ); ${ }^{\dagger}$ professionals from the Medical Clinic and Parasitic Infectious Diseases wards ( $p=0.025)$; ₹ professionals with time in profession $\geq 10.5$ years ( $p=0.001$ ); $\S$ professionals with time in profession $\geq 10.5$ years $(p=0.025)$.

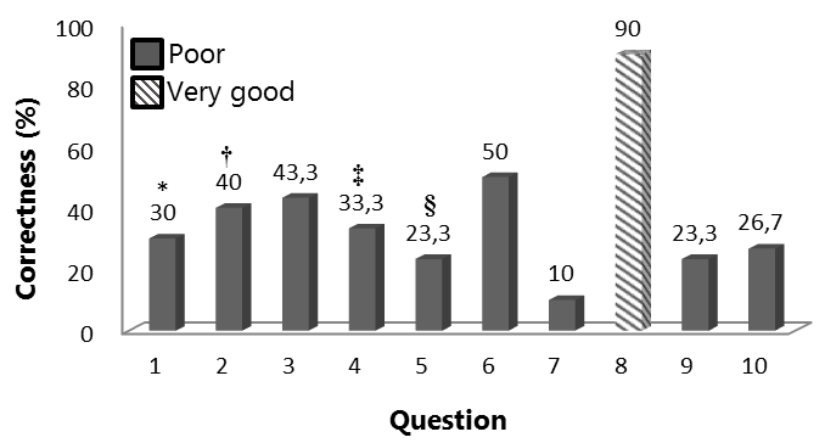

Only $16.6 \%$ of the professionals received in-service training on the subject and $10 \%$ knew a clinical protocol for sepsis management. Of the respondents, $96.6 \%$ evaluated as necessary the implementation of a sepsis management protocol in hospitalization units, and $73.3 \%$ felt motivated to implement the protocol in their unit (Table 1).

\section{DISCUSSION}

Nurses' knowledge was below the required for early identification and management of sepsis. One of the likely justifications may be insufficient permanent education, since a small portion $(16.7 \%)$ of the participants received this intervention. This indicates the urgent need for investments in the permanent updating of these professionals.

Educational interventions with nurses positively impact the level of knowledge, practice and care management. A study ${ }^{17}$ with 87 US nurses revealed improvements in early identification of sepsis $(65.8 \%$ to $87.3 \%$ ), ability to care for these patients $(62.4 \%$ to $86.6 \%)$, and team mobilization for early treatment $(66.3 \%$ to $85.6 \%)$ after a multimodal educational program with self-rated competence over sepsis. In Brazilian private hospitals, implementation of an educational program, based on SSC bundle, improved the conformity of each item over time and the total conformity of the items was associated with a reduction in mortality from $55 \%$ to $26 \%$ and a consequent reduction in hospital costs. ${ }^{18}$

A study on implementation of the sepsis protocol shows a great result on care and management indicators when analyzing the impact of the sepsis protocol initiated by nurses, the conformities with SSC bundle before and after implementation of the sepsis protocol, and the predictors of hospital mortality. 
Table 1. Training and perception about sepsis protocol. Campo Grande/MS, Brazil, 2018

\begin{tabular}{lcc}
\hline Indication & $\mathbf{N}=\mathbf{3 0}$ & $\mathbf{\%}$ \\
\hline Received in-service training on sepsis & 5 & 16,7 \\
\hline Had knowledge about some clinical sepsis management protocol & 3 & 10,0 \\
Had knowledge about the clinical sepsis management protocol of LASI* & 3 & 10.0 \\
\hline Read the clinical sepsis management protocol of LASI* & 5 & 29 \\
Considered necessary to implement a sepsis management protocol & 22 & 96.7 \\
Was motivated to implement a sepsis management protocol in his/her unit of work & 73.3 \\
\hline
\end{tabular}

* Latin American Sepsis Institute.

After implementation of the protocol, there were significant improvements in the measurement of serum lactate levels, reduced time to identify sepsis at the blood culture and at the beginning of antibiotic administration, even though it was not within the time recommended by the bundle..$^{19}$

In this study, the knowledge of the participants with time $\geq 10$ years of professional practice was greater with respect to the topics of volume resuscitation and indication for the use of vasoactive drugs, when compared to those with time $<10$ years. This finding can be explained by the greater experience of nurses with more professional practice in the care of patients affected by the most diverse causes, who require similar care in these subjects and not necessarily specific knowledge about treatment and management of sepsis. In any case, it should be noted that the knowledge of the participants in these two questions (4 and 5) was well below expectations, $33.3 \%$ and $23.3 \%$, respectively.

Only $30 \%$ of the nurses demonstrated to know the definition of sepsis of Sepsis-3. The majority (63.4\%) indicated alternative " $E$ " as correct, which introduces the definition of sepsis indicated by Sepsis-2, ${ }^{20}$ that is, based on the presence of Systemic Inflammatory Response Syndrome (SIRS). Although this is an issue addressed in the literature ${ }^{21}$ and questioned in some respects by authorities - such as LASI and the Brazilian Society of Intensive Care -, it is important that nurses know this reference, since it is a consensus of worldwide orientation.

Question 2, which focus was the signs of organic dysfunction resulting from sepsis, presented a higher percentage of correct answers by nurses in the clinical wards (IPD and MC grouped), when compared to nurses in the surgical wards. This may be associated with higher incidences of sepsis and organic dysfunction in hospitalized patients in these units, as demonstrated by a study that evaluated the performance of a sepsis-screening instrument involving both origins of patients. ${ }^{22}$

In addition, the different characteristics among these units, such as the reason for hospitalization, the therapeutic purpose, the length of hospital stay, the clinical complexity of the patients, and the presence of previous infections, should be considered. Thus, in addition to the higher incidence, clinical nurses have more practical experience regarding the organic dysfunctions resulting from infections and, consequently, sepsis.
In questions 2 and 10, which addressed the organic dysfunctions and the perfusion parameters, respectively, the most selected answer was the assertion that all the alternatives were correct, when the alternatives presented situations totally contrary to the question, which evidences the lack of knowledge of the professionals or inattention in completing the questionnaire.

In question 3, focusing on the components of qSOFA, the most selected alternative was the one that presented two correct components added to hyperlactatemia, which made the alternative incorrect. qSOFA as an instrument for the rapid evaluation of organic dysfunction at the bedside addresses clinical parameters that can be evaluated in this condition. However, measuring serum lactate requires a laboratory examination, which impairs fast and bedside evaluation, as proposed by the instrument.

Question 4 addressed adequate volume resuscitation, in which the "Does not know" alternative was the most selected (56.7\%). Question 5, however, evaluated the knowledge regarding the indication of vasopressors, where the majority missed the question (76.7\%). Although nurses are not responsible for the prescriptions of volume resuscitation and infusion of vasoactive drugs, knowledge of these indications is essential to monitor septic patients in wards, start preventive actions, inform critical changes to the physician in a timely manner, manage drugs, equipment, and supplies, and act in life-threatening emergencies, among others. The analysis of the participants' performance in question 7 evidences a lack of knowledge about the possibility to use protein colloids, albumin, and albumin serum as fluids for volume resuscitation, which indicates the field for teaching and research actions.

\section{CONCLUSIONS AND IMPLICATIONS FOR PRACTICE}

Nurses did not have sufficient knowledge about early identification and management of sepsis. The need to implement a sepsis protocol in the institution was evidenced, accompanied by awareness programs and training of the multi-professional team in order to develop skills, abilities, and attitudes in facing this serious public health problem. 
This study had some limitations, the main one being related to the use of a data collection instrument created by the authors, which was not used in previous investigations. The replication of this study in other realities tends to minimize this limitation in order to validate the result and its generalizations. In addition, the fact that it was used with professionals from a single public teaching hospital may limit the generalization of the findings.

\section{REFERENCES}

1. Singer M, Deutschman CS, Seymour CW, Shankar-Hari M, Annane D, Bauer $M$, et al. The Third International Consensus Definitions for Sepsis and Septic Shock (Sepsis-3). JAMA [Internet]. 2016 Feb; [cited 2018 Aug 20]; 315(8):801-10. Available from: https://doi.org/10.1001/jama.2016.0287

2. Dugani S, Veillard J, Kissoon N. Reducing the global burden of sepsis. CMAJ [Internet]. 2017 Jan; [cited 2018 Sep 30]; 189(1):E2-3. Available from: https://doi.org/10.1503/cmaj.160798

3. Quintano Neira RA, Hamacher S, Japiassú AM. Epidemiology of sepsis in Brazil: Incidence, lethality, costs, and other indicators for Brazilian Unified Health System hospitalizations from 2006 to 2015. PLoS One [Internet]. 2018 Apr; [cited 15 Oct 2018]; 13(4):e0195873. Available from: https://doi.org/10.1371/journal.pone.0195873

4. Barros LLS, Maia CSF, Monteiro MC. Risk factors associated to sepsis severity in patients in the Intensive Care Unit. Cad Saúde Coletiva [Internet]. 2016; [cited 2018 Sep 15]; 24(4):38896. Available from: http://www.scielo.br/scielo. php?pid=S1414462X2016000400388\&script=sci_abstract

5. Barreto MFC, Gomes Dellaroza MS, Kerbauy G, Grion CMC. Sepsis in a university hospital: a prospective study for the cost analysis of patients' hospitalization. Rev Esc Enferm USP [Internet]. 2016 Apr; [cited 2018 May 28]; 50(2):302-8. Available from:

http://www.scielo.br/pdf/reeusp/v50n2/pt_0080-6234reeusp-50-02-0302.pdf

6. Esteban A, Frutos-Vivar F, Ferguson ND, Peñuelas O, Lorente JA, Gordo F, et al. Sepsis incidence and outcome: contrasting the intensive care unit with the hospital ward. Crit Care Med [Internet]. 2007 May [cited 2018 Oct 15]; 35(5):1284-9. Available from: https://doi.org/10.1097/01.CCM.0000260960.94300.DE

7. Garrido F, Tieppo L, Pereira MDS, Freitas R, Freitas WM, Filipini $R$, et al. Ações do enfermeiro na identificação precoce de alterações sistêmicas causadas pela sepse grave. ABCS Health Sci [Internet]. 2017; [cited 2018 Aug 20]; 42(1):15-20. Available from: https://doi.org/10.7322/abcshs.v42i1.944

8. Peninck PP, Machado RC. Aplicação do algoritmo da sepse por enfermeiros na Unidade de Terapia Intensiva. Rev Rene [Internet]. 2012 Jan; [cited 2018 Aug 25]; 13(1):187-99. Available from: http://periodicos.ufc.br/rene/article/view/3793

9. Jeffery AD, Mutsch KS, Knapp L. Knowledge and recognition of SIRS and sepsis among pediatric nurses. Pediatr Nurs [Internet]. 2014 Nov/ Dec; [cited 2018 Sep 5]; 40(6):271-8. Available from:

https://www.ncbi.nlm.nih.gov/pubmed/?term=Knowledge+and +recognition+of+SIRS+and+sepsis+among+pediatric+nurses

10. Robson W, Beavis S, Spittle N. An audit of ward nurses' knowledge of sepsis. Nurs Crit Care [Internet]. 2007 Mar; [cited 2018 Sep 15]; 12(2):86-92. Available from: https://doi.org/10.1111/j.1478 5153.2007.00210.x
11. Santos JF, Alves AP, Stabile AM. Avaliação do conhecimento dos estudantes de enfermagem sobre sepse. Rev Eletr Enferm [Internet]. 2012 Oct/Dec; [cited 2018 Feb 10]; 14(4):850-6. Available from: https:// www.fen.ufg.br/fen_revista/v14/n4/pdf/v14n4a13.pdf

12. Levy MM, Evans LE, Rhodes A. The Surviving Sepsis Campaign Bundle: 2018 update. Intensive Care Med [Internet]. 2018 Jun; [cited 2018 Nov 18]; 44(6):925-8. Available from: https://dx.doi.org/10.1007/s00134018-5085-0

13. Instituto Latino-Americano de Sepse. Implementação de protocolo gerenciado de sepse: protocolo clínico. Atendimento ao paciente adulto com sepse/choque séptico [Internet]. 2017 Jun; [cited 2017 Nov 15]. Available from:

https://www.ilas.org.br/assets/arquivos/ferramentas/protocolo-detratamento.pdf

14. Rhodes A, Evans LE, Alhazzani W, Levy MM, Antonelli M, Ferrer $\mathrm{R}$, et al. Surviving Sepsis Campaign: International Guidelines for Management of Sepsis and Septic Shock: 2016. Crit Care Med [Internet]. 2017 Mar; [cited 2018 Feb 10]; 45(3):486-552. Available from: https://www.ncbi.nlm.nih.gov/pubmed/28098591

15. Frota OP, Ferreira AM, Loureiro MDR, Cheade MFM, Reis MG. O uso de equipamento de proteção individual por profissionais de enfermagem na aspiração endotraqueal. Rev Enferm UERJ (Rio de Janeiro) [Internet]. 2012 Dec; [cited 2019 Jun 18];20(no.spe 1):625-30. Available from:

https://www.e-publicacoes.uerj.br/index.php/enfermagemuerj/article/ view/5939

16. Frota OP, Loureiro MDR, Ferreira AM. Knowledge about endotracheal suctioning on the part of intensive care nursing professionals: a descriptive study. Online Braz J Nurs [Internet] 2013 Sep; [cited: 2018 Dec 14]; 12(2):546-54. Available from http://www.objnursing.uff.br/index.php/nursing/article/view/4115

17. Delaney MM, Friedman MI, Dolansky MA, Fitzpatrick JJ. Impact of a sepsis educational program on nurse competence. J Contin Educ Nurs [Internet]. 2015 Apr; [cited 2018 Sep 10]; 46(4):179-86. Available from: https://doi.org/10.3928/00220124-20150320-03

18. Noritomi DT, Ranzani OT, Monteiro MB, Ferreira EM, Santos RS Leibel $F$, et al. Implementation of a multifaceted sepsis education program in an emerging country setting: clinical outcomes and costeffectiveness in a long-term follow-up study. Intensive Care Med [Internet]. 2014 Feb; [cited 2018 Sep 10]; 40(2):182-91. Available from: https://doi.org/10.1007/s00134-013-3131-5

19. Bruce HR, Maiden J, Fedullo PF, Kim SC. Impact of nurse-initiated ED sepsis protocol on compliance with sepsis bundles, time to initial antibiotic administration, and in-hospital mortality. J Emerg Nurs [Internet]. 2015 Mar; [cited 2018 Sep 15]; 41(2):130-7. Available from: https://doi.org/10.1016/j.jen.2014.12.007

20. Williams JM, Greenslade JH, McKenzie JV, Chu K, Brown AFT, Lipman J. Systemic Inflammatory Response Syndrome, Quick Sequential Organ Function Assessment, and Organ Dysfunction: Insights From a Prospective Database of ED Patients With Infection. Chest [Internet] 2017 Mar; [cited 2018 Dec 14]; 151(3):586-96. Available from: https://doi.org/10.1016/j.chest.2016.10.057

21. Levy MM, Fink MP, Marshall JC, Abraham E, Angus D, Cook D, et al.; International Sepsis Definitions Conference. 2001 SCCM/ESICM/ ACCP/ATS/SIS International Sepsis Definitions Conference. Intensive Care Med [Internet]. 2003 Apr; [cited 2018 Dec 14]; 29(4):530-8. Available from: https://www.ncbi.nlm.nih.gov/pubmed/12664219

22. Gyang E, Shieh L, Forsey L, Maggio P. A nurse-driven screening tool for the early identification of sepsis in an intermediate care unit setting. J Hosp Med [Internet]. 2016 Feb; [cited 2018 Sep 5]; 10(2):97-103. Available from: https://doi.org/10.1002/jhm.2291 